Pediat. Res. 4: 89-95 (1970)

Developmental biochemistry hyperlysinemia infants

lysine lysine-ketoglutarate

reductase

pipecolic acid premature infants

\title{
Excretion of Pipecolic Acid by Infants and by Patients with Hyperlysinemia
}

\author{
N. C.Woody ${ }^{[58]}$ and M.B. Pupene \\ Department of Pediatrics, Tulane University School of Medicine \\ and the Charity Hospital of Louisiana, New Orleans, Louisiana, USA
}

\begin{abstract}
Extract
Pipecolic acid has been found in urine from normal infants and from children with hyperlysinemia. The reaction of pipecolic acid with ninhydrin reagent, using separation procedures in automated ion-exchange systems for amino acid analysis, produced a color constant of low value (1.21 compared with 27.6 for leucine) that could be overlooked in routine analyses of physiological fluids. Pipecolic acid was present in the urine from: four premature infants (6-23 days old) $1.2-8.1 \mu \mathrm{g} / \mathrm{mg}$ creatinine; two of four term infants (3-5 days old) 1.3 and $2.1 \mu \mathrm{g} / \mathrm{mg}$ creatinine; and one of four infants (4-11 months old) $2.1 \mu \mathrm{g} / \mathrm{mg}$. No pipecolic acid was found in the urines of four infants 14-30 months old. In patients with hyperlysinemia, the amounts of pipecolic acid excreted in the urine were: $3.1 \mu \mathrm{g} / \mathrm{mg}$ creatinine (4-year-old girl); $5.2 \mu \mathrm{g} / \mathrm{mg}$ creatinine (6-year-old boy); $6.2 \mu \mathrm{g} / \mathrm{mg}$ creatinine (9-year-old girl); and $4.8 \mu \mathrm{g} / \mathrm{mg}$.creatinine (12-year-old girl).
\end{abstract}

\section{Speculation}

The low color yield of pipecolic acid, when separated by standard automated ion-exchange analysis methods, may account for past failures to detect small amounts of this substance in physiological fluids. Amounts of pipecolic acid excreted by young infants and by children with hyperlysinemia indicate that a degradation pathway for lysine, via pipecolic acid to $\alpha$-aminoadipic acid, is operative in man.

\section{Introduction}

Pipecolic acid has been shown to be a product of lysine metabolism in rats [31-33], guinea pigs [5, 20,34], and turkeys [6, 7]. It has been detected in plants [53] and is derived from lysine in some of them [15, 24]. Certain microorganisms form pipecolic acid from $\alpha$ aminoadipic acid [3]; others derive it from lysine by pathways similar to those described for mammals $[20$, 35].

Reports of the presence of pipecolic acid in human urine are conflicting. Numerous studies of excretion of amino acids by infants, children, and adults $[2,4,8-10$, $14,16,19,21-23,25,26,28,30,36,39,41-45,47,48]$ make no mention of pipecolic acid as a normal urinary constituent, but JAGENBURG [18] detected pipecolic acid in urine from infants less than 1 year old; however, he was unable to find it in urine of adults. Pipecolic acid also has been found in the urine of a child with hyperlysinemia [49] and in urine of patients with hyperthyroidism [38]. Ghadimi et al. [13], however, attempting to detect pipecolic acid in urine from normal premature infants, infants, and adults, and from patients with hyperlysinemia were unsuccessful, and 
Armstrong et al. [1] could not detect pipecolic acid in urine from normal infants and children. GatrielD and associates [12] recently described pipecolic acid in serum, urine, spinal fluid, and tissues of a patient with mental retardation who had no demonstrable impairment of lysine metabolism, and WHITEHEAD [46] reported finding pipecolic acid in the serum of patients with kwashiorkor.

\section{Materials and Methods}

Collection and Preparation of Specimens

Twenty-four hour, nonfasting urine specimens were collected from four premature infants, four term infants, four infants less than 1 year old, and four infants over 1 year of age. The babies were fed an evaporated milk formula $(20 \mathrm{kcal} / \mathrm{oz})$ : older infants were given a general diet. Overnight $(12 \mathrm{~h})$ urine specimens were also collected from four children with hyperlysinemia. The children did not eat $4 \mathrm{~h}$ before challenge or throughout the 12-h period. Thymol was added to all specimens as a preservative [37], and levels of creatinine in urine were measured promptly. The volume usually taken for analysis by the method of SPACKMAN et al. [40] was calculated on the basis of specific gravity (standard volume taken for analysis $\left.=\frac{0.04}{\mathrm{sp} \mathrm{gr}-1.000}\right)$. A portion of urine five times this normal volume was desalted by ion exchange using a Dowex-50 column [37]. The eluate was dried in a flash evaporator, reconstituted to 1 volume, and the $\mathrm{pH}$ adjusted to 2.2. This fivefold desalted concentrate was frozen at $-20^{\circ}$ untilanalyzed.

\section{Chromatographic Separation of Amino Acids}

The automated system (54) of SPACKMAN et al. [40] as modified by ZACHARIAS and TALLEX [52] was used for analysis and separation of amino acids. This technique separates pipecolic acid sharply from other naturally occurring substances found in urine. A spherical resin [55] was used that slightly modified elution times for some amino acids. The $150-\mathrm{cm}$ column with temperature maintained at $50^{\circ}$ was used for separation. The buffer change ( $\mathrm{pH} 3.25,0.2 \mathrm{~N}$ sodium citrate followed by $\mathrm{pH} 4.25,0.2 \mathrm{~N}$ sodium citrate) was at $14.75 \mathrm{~h}$. With this system, the elution peak of pipecolic acid at $440 \mathrm{ml}$ lies between valine $(410 \mathrm{ml})$ and methionine $(537 \mathrm{ml})$ and is well separated from them (fig. 1).

The fivefold concentrate of amino acids in the urine specimens was freed of ammonia and applied to the $150-\mathrm{cm}$ by $0.9-\mathrm{cm}$ column. With buffer flow at $30 \mathrm{ml} / \mathrm{h}$, the stream-dividing pump was set to divert $6 \mathrm{ml} / \mathrm{h}$ to the spectrophotometer and the remainder of the column eluate was collected in 2-mI fractions.

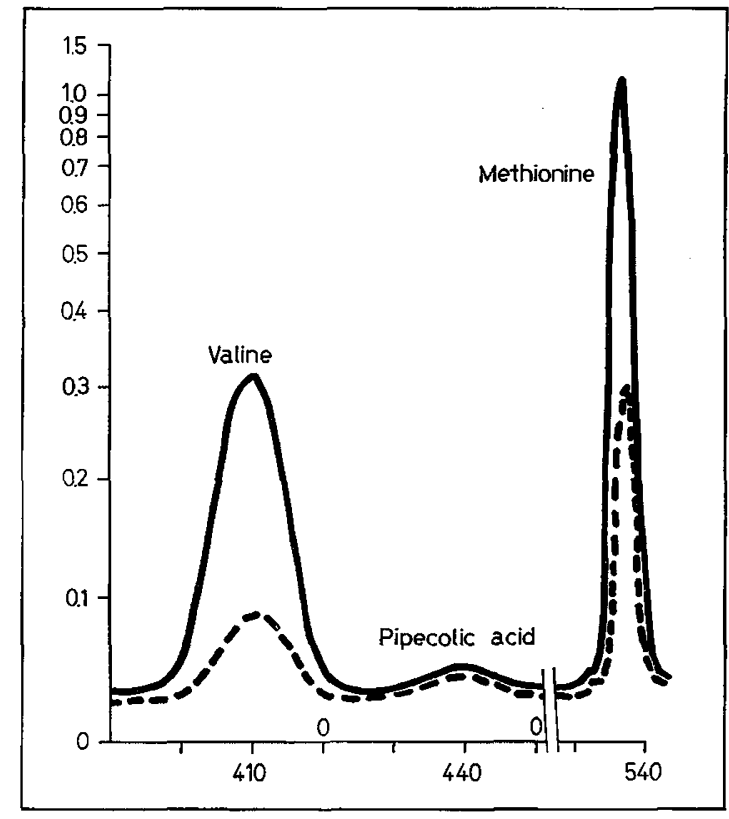

Fig. 1. Absorption curves of $1 \mu$ mole of valine, pipecolic acid, and methionine separated by the ZACHARIAS and Talley modification of the method of SPACKMAN et al. [40]. Upper trace at $570 \mathrm{~m} \mu$, lower at $440 \mathrm{~m} \mu$.

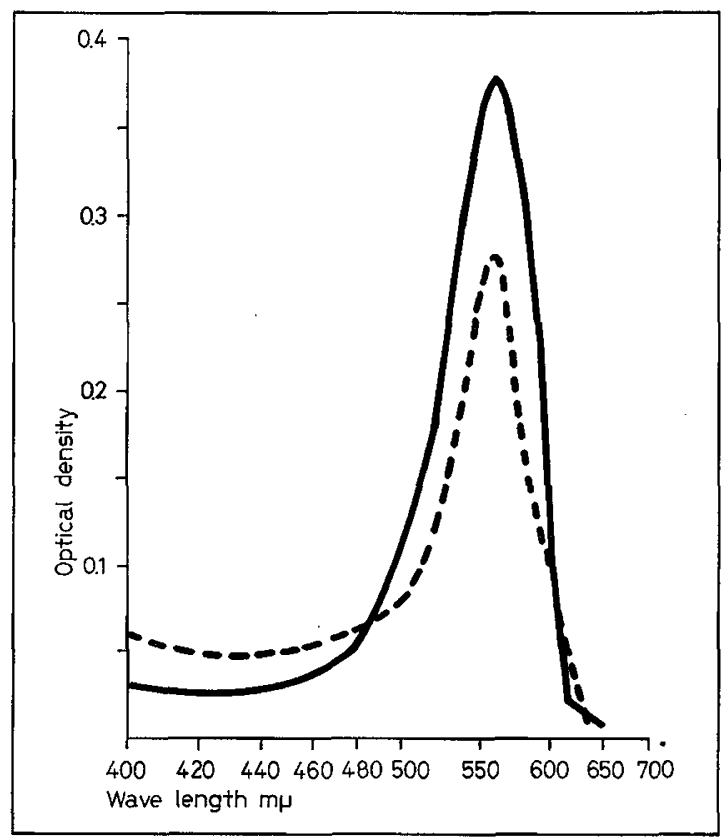

Fig. 2. Absorption spectra, using acid ninhydrin reagent of PIEZ et al. [29] of $0.1 \mu$ mole of DL-pipecolic acid (solid line) and of pooled and concentrated fractions of peak eluted at $440 \mathrm{ml}$ by the ZACHARIAS and TALLEY method [52] from the urine of a hyperlysinemic child (dashed line). Beckman DU with 1-cm cell. 
Detection and Measurement of Pipecolic Acid

Preliminary studies using standard amino acid calibration mixtures suggested reasons why pipecolic acid can easily escape detection when present in small amounts in physiologic fluids. Figure 1 shows the absorption peak produced by $1 \mu$ mole of pipecolic acid that was separated from a calibration mixture by the method of Zagharias and TALley [52]. The area below this peak reflects the low color constant produced by the reaction of pipecolic acid with the ninhydrin reagent designed for the recorder (1.21 compared with 27.6 for leucine). Because this procedure achieved a poor color yield, pipecolic acid was isolated from the urine and confirmed and quantitated by other means. Accordingly, the fractions of column eluate containing pipecolic acid (430 through $448 \mathrm{ml}$ ) were pooled, desalted by ion exchange on Dowex- 50 , and concentrated by vacuum evaporation. An aliquot of this concentrate was applied to Whatman no. 1 paper and chromatographed with butanol-acetic acid-water (12:3:5) and with phenol-water-ammonia (160: 40:1). Standard DL-pipecolic acid [56] was run simultaneously. Material from fractions corresponding to the ion-exchange elution peak at $440 \mathrm{ml}$ formed discrete spots on the chromatograms. These had $R_{F}$ values, in each solvent, identical with those of known pipecolic acid. Following the reaction with ninhydrin $0.2 \%$ in acetone), the spots from the column peak exhibited the red fluorescence under ultraviolet light that is characteristic of pipecolic acid [26]. Comparison of the size and density of the pipecolic acid-ninhydrin spots with those produced by standard pipecolic acid permitted semiquantitative estimates of the amount of pipecolic acid in the urine.

More accurate measurement of pipecolic acid in the fractions could be obtained when the ninhydrin method of PIEz et al. [29] was applied to the concentrate of column eluate. Pipecolic acid absorbs maximally at $565 \mathrm{~m} \mu$ with this reagent. Using known pipecolic acid mixtures as standards, the acid ninhydrin reaction was used to determine the amount of pipecolic acid in the concentrate of the pooled fractions comprising the $440-\mathrm{ml}$ peak. As with the standards, the pooled fractions from this peak showed maximal absorption with acid ninhydrin at $565 \mathrm{~m} \mu$ (fig. 2).

\section{Identification \\ Results}

The conclusion that the substance in the peak eluted at $440 \mathrm{ml}$ that reacted with ninhydrin is pipecolic acid appears justified because its behavior is identical with that of known pipecolic acid with regard to: $R_{F}$ values by paper chromatography, elution behavior on ion-

Table I. Pipecolic acid levels in urine from control subjects

\begin{tabular}{|c|c|c|c|c|c|c|}
\hline \multirow[b]{2}{*}{ Control subjects } & \multirow[b]{2}{*}{ Age } & \multicolumn{2}{|c|}{ Urine } & \multicolumn{2}{|c|}{ Paper chromatography } & \multirow{2}{*}{$\begin{array}{l}\text { Acid } \\
\text { ninhydrin } \\
\text { method, } \\
\mu \mathrm{g} / \mathrm{mg} \\
\text { creatinine }\end{array}$} \\
\hline & & $\overline{\mathrm{Sp} g r}$ & $\begin{array}{c}\text { Creatinine, } \\
\mathrm{mg} / \mathrm{ml}\end{array}$ & $\begin{array}{l}\text { Pipecolic } \\
\text { acid spot }^{1}\end{array}$ & $\begin{array}{l}\text { Ultraviolet } \\
\text { fluorescence }\end{array}$ & \\
\hline Premature & 6 days & 1.004 & 0.18 & + & + & 1.2 \\
\hline Premature & 6 days & 1.006 & 0.12 & + & + & 4.6 \\
\hline Premature & 9 days & 1.004 & 0.10 & + & + & 1.2 \\
\hline Premature & 23 days & 1.005 & 0.10 & + & + & 8.1 \\
\hline Neonate & 3 days & 1.022 & 2.18 & 0 & 0 & 0 \\
\hline Neonate & 4 days & 1.009 & 0.13 & + & + & 2.1 \\
\hline Neonate & 5 days & 1.011 & 0.79 & + & + & 1.3 \\
\hline Neonate & 5 days & 1.004 & 0.22 & 0 & 0 & 0 \\
\hline Infant & 4 months & 1.008 & 0.23 & 0 & 0 & 0 \\
\hline Infant & 5 months & 1.010 & 0.28 & 0 & 0 & 0 \\
\hline Infant & 8 months & 1.009 & 0.17 & + & + & 2.1 \\
\hline Infant & 11 months & 1.027 & 0.73 & 0 & 0 & 0 \\
\hline Infant & 14 months & 1.020 & 0.38 & 0 & 0 & 0 \\
\hline Infant & 24 months & 1.020 & 0.54 & 0 & 0 & 0 \\
\hline Infant & 24 months & 1.013 & 0.53 & 0 & 0 & 0 \\
\hline Infant & 30 months & 1.012 & 0.32 & 0 & 0 & 0 \\
\hline
\end{tabular}

${ }^{1}$ Ninhydrin reaction and $R_{F}$ value identical with those of known pipecolic acid. 
Table II. Pipecolic acid levels in urine from hyperlysinemic patients

\begin{tabular}{|c|c|c|c|c|c|c|}
\hline \multirow[b]{2}{*}{$\begin{array}{l}\text { Hyperlysinemic } \\
\text { patients }\end{array}$} & \multirow[b]{2}{*}{ Age, yr } & \multicolumn{2}{|c|}{ Urine } & \multicolumn{2}{|c|}{ Paper chromatography } & \multirow{2}{*}{$\begin{array}{c}\text { Acid } \\
\text { ninhydrin } \\
\text { method, } \\
\mu \mathrm{g} / \mathrm{mg} \\
\text { creatinine }\end{array}$} \\
\hline & & Sp gr & $\begin{array}{c}\text { Creatinine, } \\
\mathrm{mg} / \mathrm{ml}\end{array}$ & $\begin{array}{l}\text { Pipecolic } \\
\text { acid spot }^{1}\end{array}$ & $\begin{array}{l}\text { Ultraviolet } \\
\text { fluorescence }\end{array}$ & \\
\hline Sister & 9 & 1.015 & 0.70 & + & + & 6.2 \\
\hline Brother & 6 & 1.013 & 0.07 & + & + & 5.2 \\
\hline Sister & 4 & 1.018 & 0.05 & + & + & 3.1 \\
\hline Cousin & 12 & 1.010 & 0.35 & + & + & 4.8 \\
\hline
\end{tabular}

${ }^{1}$ Ninhydrin reaction and $R_{F}$ value identical with those of known pipecolic acid.

exchange column analysis, cherry-red fluorescence of the ninhydrin product upon exposure to ultraviolet light, and maximal absorption at $565 \mathrm{~m} \mu$ after reaction with acid ninhydrin reagent.

\section{Pipecolic Acid Excretion by Normal Infants}

Table I shows the amounts of pipecolic acid excreted in urine from four of four premature infants, three of four term neonates, and one of four infants under 1 year of age. No pipecolic acid was excreted by four older infants, 14-30 months of age. The amounts excreted varied from $8.1 \mu \mathrm{g} / \mathrm{mg}$ creatinine (in a premature infant) to $1.3 \mu \mathrm{g} / \mathrm{mg}$ creatinine (in a term infant).

Pipecolic Acid Excretion by Patients with Hyperlysinemia

Table II shows the levels of pipecolic acid in urine from four patients with hyperlysinemia; values range from 4.8 to $6.2 \mu \mathrm{g} / \mathrm{mg}$ creatinine.

\section{Discussion}

Pipecolic acid was eluted by $100-\mathrm{cm}$ ion-exchange column chromatography [41] from the urine of a 1-year-old child [18]. The eluate emerged as a peak (designated as $\mathrm{G}$ ) between valine and methionine. Also, pipecolic acid was found by paper chromatography [18] in urine of premature and term infants less than 76 days old, but the frequency of detection was not reported. FowLer et al. [11], using column chromatography [41], found a peak (which they called no.9) between valine and methionine; however, they did not identify it. The peak occurred in urine from two of three premature infants, two of two neonates, and three of three infants, but was not found in any subject over 5 months old. GatField et al. [12] used methods almost identical with those described here and reported finding pipecolic acid in serum of normal children 2-15 years of age, but did not detect pipecolic acid in the urine. In their 18-month-old patient with elevated serum pipecolate, pipecolic acid in the urine was found to average $5.2 \mu \mathrm{g} / \mathrm{mg}$ creatinine $(0.04$ $\mu \mathrm{mole} / \mathrm{mg}$ creatinine). When their patient and four control subjects (3-7 years old) were given $200 \mathrm{mg} / \mathrm{kg}$ of L-lysine by mouth, there was no alteration in the level of pipecolic acid in the serum or urine after $6 \mathrm{~h}$.

When pipecolic acid was used with the ninhydrin reagent employed for automated ion-exchange amino acid separations, the color-yield of pipecolic acid was so low that $1 \mu$ mole recorded an unimpressive peak. Because color values are low, routine analytic ionexchange methods permit pipecolic acid to be easily overlooked. Using paper chromatographic methods and $0.2 \%$ ninhydrin in acetone [37] for color development, amounts of pipecolic acid below $0.3 \mu \mathrm{g}$ seldom can be detected on one-dimensional chromatograms. Such small amounts yield bluish spots, but red fluorescence under ultraviolet light, which is characteristic of pipecolic acid, does not usually occur with amounts less than $0.4 \mu \mathrm{g}$. Thus, small quantities may be missed by conventional screening methods using paper chromatography whenever dependence is placed on ultraviolet fluorescence for confirmation.

Studies bearing on lysine metabolism by the human $[1,12,17,50,51]$ indicate that alternate pathways for lysine degradation exist (fig. 3), and that the pathway (II) via conversion of lysine to saccharopine by lysineketoglutarate reductase is probably the major one. Detection of pipecolic acid in urine from four children with hyperlysinemia demonstrated that the pathway via pipecolic acid [2] was functioning in these hyperlysinemic patients. The small amounts of pipecolic acid that were excreted in the urine, when compared with the large amounts of lysine simultaneously excreted by these patients, suggest that this path was normally a secondary one, which in these patients, had been pressed into maximal utilization by substrate loading. This would be comparable to the situation in 


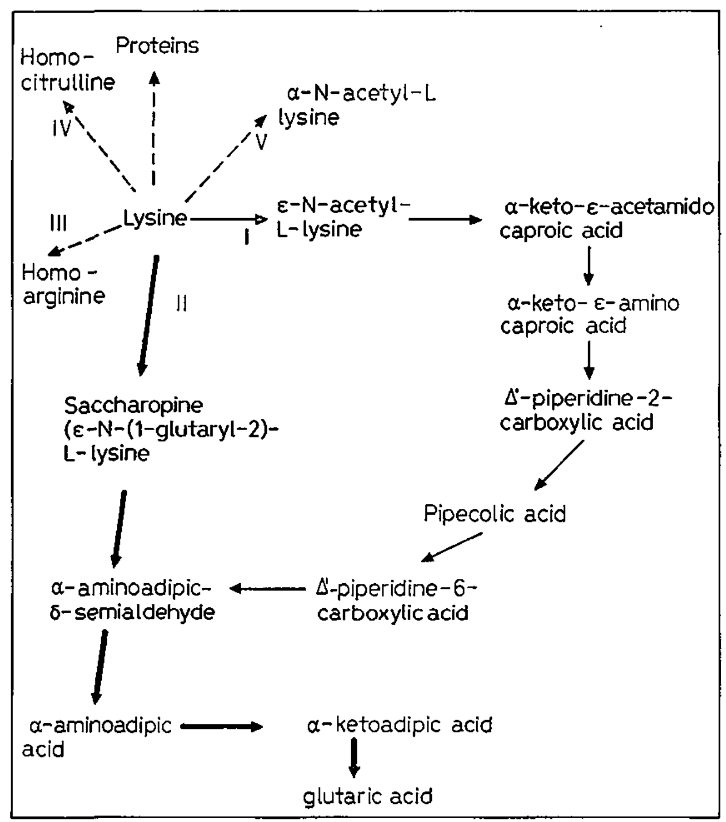

Fig. 3. Lysine metabolic pathways for man.

phenylketonuria and histidinemia where alternate pathways are utilized.

The presence of pipecolic acid in the urine of premature infants and neonates, and absence from urine of older infants, coupled with the observation that premature infants and neonates excrete more lysine than older subjects $[8,9,27,39]$, implies that lysineketoglutarate reductase activity may be reduced in the newly born and be induced by substrate loading during the initial weeks of life. Since GaTFIELD and colleagues [12] found renal tubular reabsorption of pipecolic acid to be very efficient in normal children and in the patient with hyperpipecolatemia, the pipecolic aciduria observed in neonates and in patients with hyperlysinemia might result from a renal tubular reabsorption defect, age-related in the neonates and secondary to the inhibition of enzyme activity by an accumulated metabolite in the hyperlysinemic patients.

\section{Summary}

Pipecolic acid has been measured in the urine of premature and term neonates and of infants. One of four infants less than 1 year old, two of four term neonates, and four of four prematures excreted pipecolic acid in the urine. It was not found in urines of four infants over 1 year of age. Four children with hyperlysinemia excreted amounts of pipecolic acid that demonstrated that a pathway for lysine degradation, via pipecolic acid to $\alpha$-aminoadipic acid, was functioning in these patients, that this pathway had been pressed into maximal utilization by the high tissue lysine levels of these patients, and that in hyperlysinemic patients this pathway was a secondary one for lysine degradation. These findings support the thesis $[12,17,50,51]$ that the major path of lysine degradation in man is through conversion (by lysine-ketoglutarate reductase) of lysine to saccharopine en route to $\alpha$-aminoadipic acid.

Neonates excrete pipecolic acid at levels exceeding those found for older infants, suggesting that lysineketoglutarate reductase activity may be reduced in the newly born and become enhanced by substrate loading during the first weeks of life.

\section{References and Notes}

1. Armstrong, M.D.; Robinow, M. and Andrews, I. M.: A case of hyperlysinemia: Biochemical and clinical observations. Pediatrics 39: 546 (1967).

2. Armstrong, M.D.; Yates, K. U. and Conneliy, J.P.: Amino acid excretion of newborn infants during the first twenty-four hours of life. Pediatrics 33: 975 (1964).

3. Aspen, A.J. and Meister, A.: Conversion of $\alpha$ aminoadipic acid to L-pipecolic acid by Aspergillus nidulans. Biochemistry 1: 606 (1962).

4. Berry, H.K.: Amino acid excretion in urine of normal infants and children. Pediatrics 25: 983 (1960).

5. Borsook, H.; Deasay, C. L.; HaAgen-Smit, A. J.; Keighlex, G. and Lowy, P.H.: The degradation of $\mathrm{L}$-lysine in guinea pig liver homogenate: formation of $\alpha$-aminoadipic acid. J. biol. Ghem. 176: 1383 (1948).

6. Boulanger, P.; Bertrand, J. et Osteux, R. : Désamination de l'ornithine et de la lysine sélectivement marquées par la L-amino acide-deshydrogenase du foie de dindon (Meleagris gallopavo L.). Biochim. biophys. Acta 26: 143 (1957).

7. Boulanger, P. et Osteux, R.: Action de la Laminoacide-deshydrogenase du foie de dindon (Meleagris gallopavo L.) sur les acides amines basiques. Biochim. biophys. Acta 21: 552 (1956).

8. Burtrs, C.A. and WARren, K.S.: Identification of urinary constituents isolated by amino-exchange chromatography. Clin. Chem. 14: 290 (1968).

9. Dustin, J.P.; Moore, S. and Brgwood, E.J.: Chromatographic studies on the excretion of amino acids in early infancy. Metabolism 4: 75 (1955).

10. Evered, D.F.: The excretion of amino acids by the human. Biochem. J. 62: 416 (1956).

11. Fowler, D.I.; Norton, P.M.; Cheung, M.W. and PRATT, E.L.: Observations on the urinary 
amino acid excretion in man: Influence of age and diet. Arch. Biochem. Biophys. 68: 452 (1957).

12. Gatfield, P.D.; Taller, E.; Hinton, G.G.; Wallace, A.G.; Abdelnour, G.M. and Haust, M.D.: Hyperpipecolatemia: A new metabolic disorder associated with neuropathy and hepatomegaly. Canad.med. Ass. J. 99: 1215 (1968).

13. Gradimi, H.; Binnington, V.I. and Pecora, P.: Hyperlysinemia associated with mental retardation. New Engl.J. Med. 273: 723 (1965).

14. Ghadimi, H. and Shwachman, H.: Evaluation of amino-aciduria in infancy and childhood. Amer.J. Dis. Child. 99: 457 (1960).

15. Grobbelaar, N. and Stewart, F. G.: Pipecolic acid in Phaseolus vulgaris: Evidence on its derivation from lysine. J.Amer.chem. Soc. 75: 4341 (1953).

16. HIER, S.W.: Urinary excretion of individual amino acids on normal and low protein diets. Trans. N.Y. Acad. Sci. 10: 280 (1948).

17. Hutzler, J. and Dancis, J.: Conversion of lysine to saccharopine by human tissues. Biochim. biophys. Acta 158: 62 (1968).

18. JAGEnBURG, O.R.: The urinary excretion of free amino acids and other amino acid compounds by the human. Scand.J. clin. Lab. Invest. Suppl. 43 ad 11: (1959).

19. Kirsner, J. B.; ShefFner, A.L. and PAlmer, W.L. : Studies on amino acid excretion in man. III. Amino acid levels in plasma and urine of normal men fed diets of varying protein content. J. clin. Invest. 28: 716 (1949).

20. Lindstedt, S.; Lindstedt, G. and Mrtoma, C.: Studies on the metabolism of lysine and 5-hydroxylysine. Arch. biochem. Biophys. 119: 336 (1967).

21. Lo Branco, S.: L'aminoaciduria nel bambino del primo anno di vita. Lattante 24: 781 (1953).

22. Lo BiAnco, S. : Determinazione dell'aminoaciduria nel bambino sano del $2^{\circ}$ al $12^{\circ}$ anno. Lattante 25 : 449 (1954).

23. Loeb, H.; Engelen, M. et Geffel, R. van: Etude de l'amino-acidurie du nourrisson normale. Acta paediat. belg. 10: 145 (1956).

24. LowY, P.H.: The conversion of lysine to pipecolic acid by Phaseolus vulgaris. Arch. Biochem. Biophys. 47: 228 (1953).

25. MABry, C.C. and Tod, W.R.: Quantitative measurement of individual and total free amino acids in urine. J. Lab. clin. Med. 61: 146 (1963).

26. Morrison, R.I.: The isolation of L-pipecolic acid from Trifolium repens. Biochem.J. 53: 474 (1953).

27. Norton, P.M.; Pratt, E.L. and Hasselmeyer, E.: Urinary amino acid excretion by premature infants. Amer.J. Dis. Child. 88: 659 (1954).

28. O'Brien, D. and Butterfield, L.J.: Further studies on renal tubular conservation of free amino acids in early infancy. Arch. Dis. Childh. 38: 437 (1963).

29. Piez, K. A.; Irreverre, F. and WolfF, H. L. The separation and determination of cyclic amino acids. J. biol. Chem. 223: 687 (1956).

30. Rivier, G. et Jeanneret, M.-R.: Observations sur l'aminoacidurie du nourrisson bien-portant. Helv. paediat. Acta 11: 489 (1956).

31. Rothstein, M. and Greenberg, D. M.: The metabolism of DL-pipecolic acid-2-C ${ }^{14}$. J.biol. Chem. 235: 714 (1960).

32. Rothstein, M. and MilleR, L.L. : The conversion of L-lysine-6-C $\mathrm{C}^{14}$ to pipecolic acid in the rat. J. Amer. chem. Soc. 75: 4371 (1953).

33. Rothstein, M. and Mrller, L.L.: The conversion of lysine to pipecolic acid in the rat. J.biol. Chem. 211: 851 (1954).

34. Rothitein, M. and Mrller, L. L.: The metabolism of L-lysine-6-C ${ }^{14}$. J. biol. Chem. 206: 243 (1954).

35. Schweet, R.S.; Holden, J.T. and Lowy, P.H.: The metabolism of lysine in neurospora. J.biol. Chem. 211: 517 (1954).

36. Sereni, F.; MaNamara, H.; Shibuya, M.; Kretchemer, N. and Barnett, H.L.: Concentration in plasma and rate of urinary excretion of amino acids in premature infants. Pediatrics 15 : 575 (1955).

37. Sмттн, I.: Chromatographic and electrophoretic technics; 2nd ed. (Interscience Publishers, New York 1960).

38. SonADA, Y.: Urinary amino acids of hyperthyroid patients. Proc. Japan Acad. 33: 162 (1957); cit. JAGENBURG [18].

39. Soupart, P.: Urinary excretion of free amino acids in normal adult man and woman. Glin. chim. Acta 4: 265 (1959).

40. Spackman, D.H.; Stein, W.H. and Moore, S.: Automatic recording apparatus for use in chromatography of amino acids. Anal. Chem. 30: 1190 (1958).

41. STEIN, W.H.: A chromatographic investigation of the amino acid constituents of normal urine. J. biol. Chem. 201: 45 (1953).

42. Thompson, E.; Lindor, R.; Jones, G.T.; Howie, R.N. and Throughton, W.D.: Urinary and serum amino-acid studies in premature and fullterm infants. Austr.paediat. J. 4: 1 (1968).

43. UlRIGH, J.A.: Urinary excretion of amino acids by human subjects on unrestricted diets. Proc. Mayo Clin. 29: 210 (1954).

44. Wallraff, E.B.; Brodie, E.C. and Borden, A.L.: Urinary excretion of amino acids in pregnancy. J.clin. Invest. 29: 1542 (1950).

45. Westald, R.G.: The amino acids and other ampholytes of urine. 3. Unidentified substances ex- 
creted in normal human urine. Biochem.J. 60: 247 (1955).

46. Whitehead, R.G.: An unidentified compound in the serum of children with kwashiorkor. (Proteincalorie-malnutrition.) Nature, Lond. 204: 389 (1964).

47. Woodson, H.W.; Hier, S.W.; Solomon, J.D. and BERGeIN, O.: Urinary excretion of amino acids by human subjects on normal diets. J. biol. Chem. 172: 613 (1948).

48. Woolf, L.I. and Norman, A.P.: The urinary excretion of amino acids and sugars in early infancy. J. Pediat. 50: 271 (1957).

49. Woody, N.G.: Hyperlysinemia. Amer.J.Dis. Ghild. 108: 543 (1964).

50. Woody, N.G.; Hutzler, J. and Dancis, J.: Further studies of hyperlysinemia. Amer.J.Dis. Child. 112: 577 (1966).

51. Woody, N.C.; Ong, E.B. and Pupene, M.B.: Paths of lysine degradation in patients with hyperlysinemia. Pediatrics 40: 986 (1967).
52. Zacharias, R.M. and Talley, E.A.: Elution behavior of naturally occurring ninhydrin-positive compounds during ion-exchange chromatography. Anal. Chem. 34: 1551 (1962).

53. Zachartas, R. M.; Thompson, J. F. and Stewart, F. G.: The detection, isolation and identification of pipecolic acid as a constituent of plants. J. Amer. chem. Soc. 74: 2949 (1952).

54. Automatic amino acid analyzer, model 120, Beckman Instruments, Inc., Spinco Division, Palo Alto, GA.

55. Biorad Q-150-S, Biorad Laboratories, Richmond, GA.

56. Obtained from Galbiochem, Los Angeles, CA.

57. Supported by Public Health Service Grant no. HD-02920.

58. Requests for reprints should be addressed to: N.G.Woody, M.D., Department of Pediatrics, Tulane University School of Medicine, $1430 \mathrm{Tu}-$ lane Avenue, New Orleans, LA 70112, USA.

59. Accepted for publication July 22, 1969. 